\title{
Analysis of Worring among Lecturers of Indonesian Bethel Theology on Covid-19
}

\author{
Gernaida K.R. Pakpahan \\ Lecturer of STT Bethel Indonesia
}

\begin{abstract}
The purpose of this research is to analyze the worry among the lectures of Bethel Theological Seminary concerning Covid-19. The research is using mixed method, which is combination of both qualitative and quantitative method. It employs both descriptive quantitative and phenomenological investigation approaches. The results of quantitative method is triangulated with the qualitative results. The results show that the lecturers of Bethel Theological Seminary do not worry about Covid-19. However, in the future, they may worry, especially if information concerning Covid-19 is spreading uncontrollably. Therefore, the researcher suggest that the stakeholders filter the information regarding Covid-19, so that it may not raise anxiety among those lecturers.
\end{abstract}

Keywords: Covid-19, worrying, spreading, anxiety.

\section{Introduction}

Beginning in 2020, the world was rocked by the spread of co-19 from Wuhan which infected many people in many countries. Covid-19 is a humanitarian pandemic that has caused many victims to be positively infected. Among those infected, some recovered, but many also died. The pvidemic covid-19 issue is an interesting phenomenon that is studied and analyzed. That is what encourages scientists, economic practitioners, leaders in various fields of life, and including the general public to give their views on this virus ${ }^{1}$. His views and analysis cover health, social, economic and even political aspects. Pademi covid-19 has a significant impact on the conditions of human life in general, including the emergence of anxiety, fear, concern and anxiety which then affects humans both physically and psychologically ${ }^{2}$.

Research results show that computer anxiety impacts on a person's poor skill, performance, and efficacy in using computers ${ }^{3-5}$. So the results of previous studies indicate that concerns are strategic issues that need to be addressed immediately. But apparently there is no specific research that addresses the concerns of co19 in the world of education. Based on the explanation above, it appears that research on STTBI lecturers' concerns about co-19 is an important thing to do. The research was intended to study and analyze the extent to which the impact of co-19 influenced the concerns of STTBI lecturers. From the results of the aforementioned research, it is expected to be a reference for treatment for lecturers who are worried because of co-19.

\section{Materials and Method}

The method used in this research is mixed method or combination research that combines quantitative research method and qualitative research method. Conceptually, anxiety is a universal human experience that impacts on the physical, mental, social and spiritual conditions of humans. Operationally, anxiety is a condition in which a person experiences anxiety, fear, tension, anxiety, anger that affects his whole life. The focus of this research (ie worries) can not only be seen and/or discussed positivistically from the outside, but it also needs to be seen and examined more deeply. In the context of such understanding, combination research is a method that can accommodate these needs.

The combined strategy that will be carried out in this study is concruent triangulation ${ }^{6}$. In this case, the data generated from quantitative research is triangulated with data generated from qualitative research. When the data 
from both studies are well confirmed, the research data can be declared valid. For this reason, it is necessary to explain the specifications of both studies.

Quantitative research method were carried out using a descriptive qualitative approach (1 variable and
1 sample group). The variables studied were worries, while the sample group studied was STTBI lecturers. The number of STTBI lecturers is 60 people. Sampling is done randomly using the help of Nomogram Herry King at an error rate of 0.1 which results in a sample of 30 people.

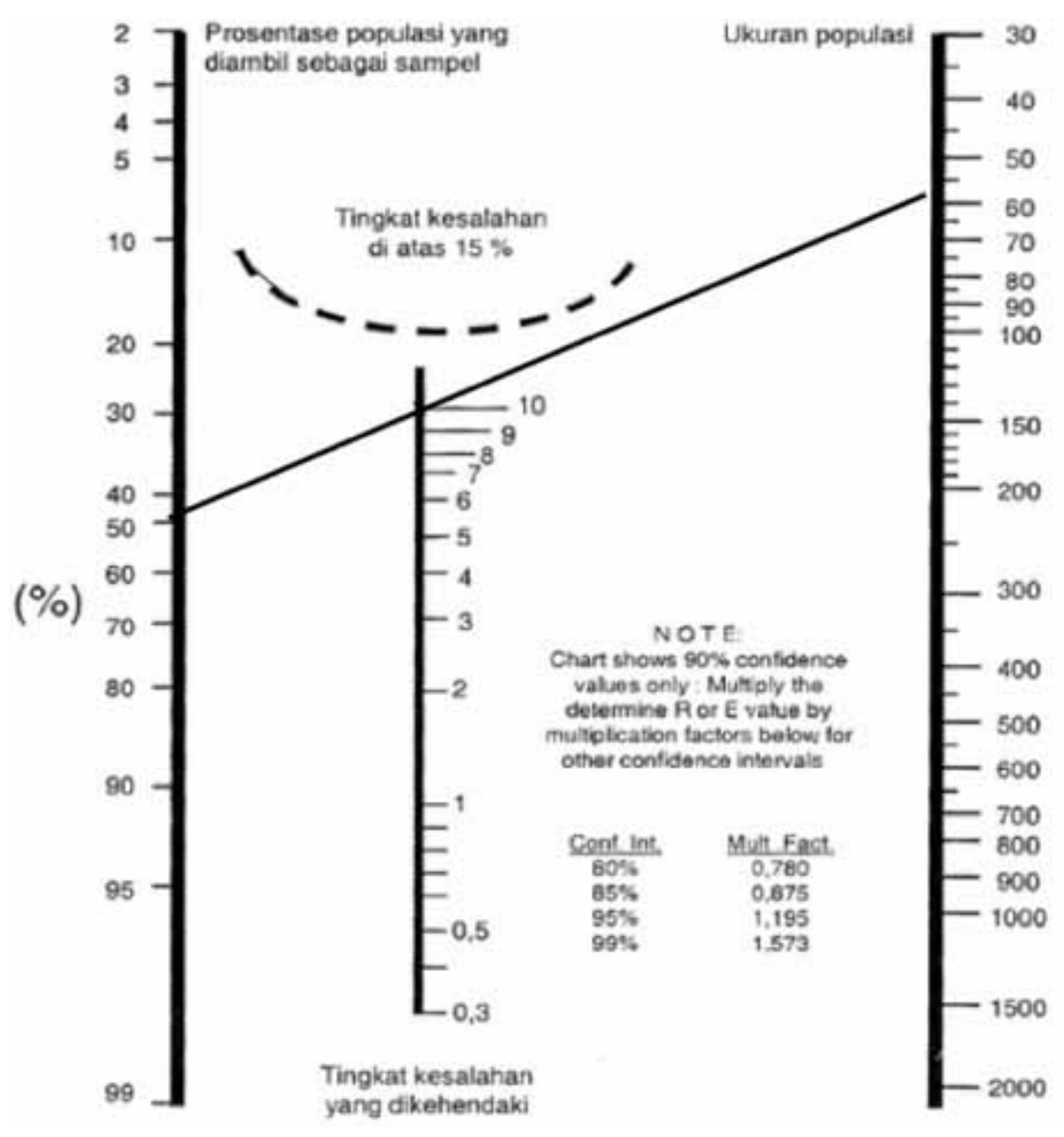

Figure 1. Calculation of the Number of Research Samples

Research data is measured on an interval scale, and collected by a questionnaire in the form of a statement with a choice of answers on a Likert scale. The questionnaire was arranged based on 3 indicators: feelings, experience, and fear of impact. The questionnaire was tested for validity and reliability then used to collect data. The collected data were analyzed by descriptive t-test. Qualitative research is used to test natural subjects. In this study, the qualitative research approach used is phenomenology. Researchers become the main instrument in research, and collect data with in-depth interview techniques and Focus Group Discussions. The research informants were taken by purposive technique and followed by snow ball sampling. Data validation was done by triangulation, and analyzed using the Spradley model of taxonomic analysis techniques. The results to be sought in the form of meaning is not just a conclusion. In this case what is being sought is the meaning of the level or hierarchy of STTBI lecturers' concerns for Covid 19. 


\section{Results}

\section{Quantitative Research Results:}

Instrument Validity and Reliability: This test is a indicator of anxiety. Thus there are 3 test results in accordance with the number of indicators of this study. There are 3 instruments with each instrument having as many as 6,6 , and 4 . The following are the results of testing the instruments that have been carried out.
Table 1. Indicator Reliability Test Results

\begin{tabular}{|c|c|}
\hline \multicolumn{2}{|c|}{ Reliability Statistics } \\
\hline Cronbach's Alpha & N of Items \\
\hline .860 & 6 \\
\hline
\end{tabular}

The instrument for this indicator has a Cronbach's Alpha coefficient of 0.860 . This value is higher than the value that becomes the reliability standard that is 0.6 . Thus, this instrument has good reliability.

Table of Test Results of Indicator Validity 1

\begin{tabular}{|c|c|c|c|c|}
\hline \multicolumn{5}{|c|}{ Item-Total Statistics } \\
\hline & $\begin{array}{c}\text { Scale Mean if Item } \\
\text { Deleted }\end{array}$ & $\begin{array}{c}\text { Scale Variance if Item } \\
\text { Deleted }\end{array}$ & $\begin{array}{c}\text { Corrected Item-Total } \\
\text { Correlation }\end{array}$ & $\begin{array}{c}\text { Cronbach's Alpha if } \\
\text { Item Deleted }\end{array}$ \\
\hline $\mathrm{I} 1 \mathrm{Q} 1$ & 10.0000 & 11.250 & .508 & .861 \\
\hline $\mathrm{I} 1 \mathrm{Q} 2$ & 10.2121 & 10.485 & .653 & .837 \\
\hline $\mathrm{I} 1 \mathrm{Q} 3$ & 10.7576 & 10.377 & .759 & .820 \\
\hline $\mathrm{I} 1 \mathrm{Q} 4$ & 10.4848 & 9.570 & .698 & .829 \\
\hline $\mathrm{I} 1 \mathrm{Q} 5$ & 10.6667 & 10.604 & .734 & .825 \\
\hline $\mathrm{I} 1 \mathrm{Q} 6$ & 9.8485 & 10.070 & .606 & .848 \\
\hline
\end{tabular}

Of the 6 questions in this instrument, all of them had a Corrected Item-Total Correlation coefficient above 0.3. Thus, all question items are valid.

Indicator Reliability Test Results Table 2

\begin{tabular}{|c|c|}
\hline \multicolumn{2}{|c|}{ Reliability Statistics } \\
\hline Cronbach's Alpha & N of Items \\
\hline .793 & 6 \\
\hline
\end{tabular}

The instrument for this indicator has a Cronbach's Alpha coefficient of 0.793. This value is higher than the value that becomes the reliability standard that is 0.6 . Thus, this instrument has good reliability.

Validity Test Results Table Indicator 2

\begin{tabular}{|c|c|c|c|c|}
\hline \multicolumn{5}{|c|}{ Item-Total Statistics } \\
\hline & $\begin{array}{c}\text { Scale Mean if Item } \\
\text { Deleted }\end{array}$ & $\begin{array}{c}\text { Scale Variance if Item } \\
\text { Deleted }\end{array}$ & $\begin{array}{c}\text { Corrected Item-Total } \\
\text { Correlation }\end{array}$ & $\begin{array}{c}\text { Cronbach's Alpha if } \\
\text { Item Deleted }\end{array}$ \\
\hline $\mathrm{I} 2 \mathrm{Q} 1$ & 11.6364 & 11.426 & .186 & .824 \\
\hline $\mathrm{I} 2 \mathrm{Q} 2$ & 12.2121 & 8.047 & .667 & .729 \\
\hline $\mathrm{I} 2 \mathrm{Q} 3$ & 12.7576 & 8.064 & .710 & .718 \\
\hline $\mathrm{I} 2 \mathrm{Q} 4$ & 13.4242 & 9.814 & .398 & .794 \\
\hline $\mathrm{I} 2 \mathrm{Q} 5$ & 13.0909 & 8.273 & .760 & .709 \\
\hline $\mathrm{I} 2 \mathrm{Q} 6$ & 13.3939 & 8.746 & .546 & .762 \\
\hline
\end{tabular}


Of the 6 questions in this instrument, 5 of them have Corrected Item-Total Correlation coefficient above 0.3. Thus, the 5 question items are valid. There is only 1 invalid item, item number 1 . As such, this item cannot be counted as part of this instrument.

\section{Indicator Reliability Test Results Table 3}

\begin{tabular}{|c|c|}
\hline \multicolumn{2}{|c|}{ Reliability Statistics } \\
\hline Cronbach's Alpha & N of Items \\
\hline .781 & 4 \\
\hline
\end{tabular}

The instrument for this indicator has a Cronbach's Alpha coefficient of 0.781 . This value is higher than the value that becomes the reliability standard that is 0.6 . Thus, this instrument has good reliability.

Table of Test Results of Indicator Validity 3

\begin{tabular}{|c|c|c|c|c|}
\hline \multicolumn{5}{|c|}{ Item-Total Statistics } \\
\hline & $\begin{array}{c}\text { Scale Mean if Item } \\
\text { Deleted }\end{array}$ & $\begin{array}{c}\text { Scale Variance if Item } \\
\text { Deleted }\end{array}$ & $\begin{array}{c}\text { Corrected Item-Total } \\
\text { Correlation }\end{array}$ & $\begin{array}{c}\text { Cronbach's Alpha if } \\
\text { Item Deleted }\end{array}$ \\
\hline I3Q1 & 8.7273 & 2.955 & .611 & .719 \\
\hline I3Q2 & 8.5152 & 2.820 & .657 & .695 \\
\hline I3Q3 & 8.7273 & 2.830 & .544 & .751 \\
\hline I3Q4 & 8.9394 & 2.684 & .555 & .749 \\
\hline
\end{tabular}

Of the 4 questions in this instrument, all of them had a Corrected Item-Total Correlation coefficient above 0.3 . Thus, all question items are valid. Description of Worry Variable Data

The values in the anxiety variable are obtained by averaging the values of each instrument on the three research indicators. There are 33 respondents who answered as many as 15 instrument items. In accordance with the instrument that has been developed, the range of lecturers' anxiety values is from 1 to 4 . In fact, the lowest concern that lecturers have is 1 , and the highest concern is at the level of 3.47 as shown in the following table.

\section{Descriptive Statistics Calculation Results Table}

\begin{tabular}{|l|c|c|c|c|c|}
\hline \multicolumn{7}{|c|}{ Descriptive Statistics } \\
\hline & $\mathbf{N}$ & Minimum & Maximum & Mean & Std. Deviation \\
\hline Kekuatiran & 33 & 1.00 & 3.47 & 2.3778 & .50295 \\
\hline Valid N (listwise) & 33 & & & & \\
\hline
\end{tabular}

The average lecturer concern is 2.37 in the range 1-4. In this case, on a scale of 1-4, the boundary between worrying and not worrying is at 2.5. Thus, while it can be said that the lecturer is not worried about the existence of Covid-19 because worries are only worth 2.37 (less than 2.5). The distribution of lecturer worries is shown in the following histogram. 


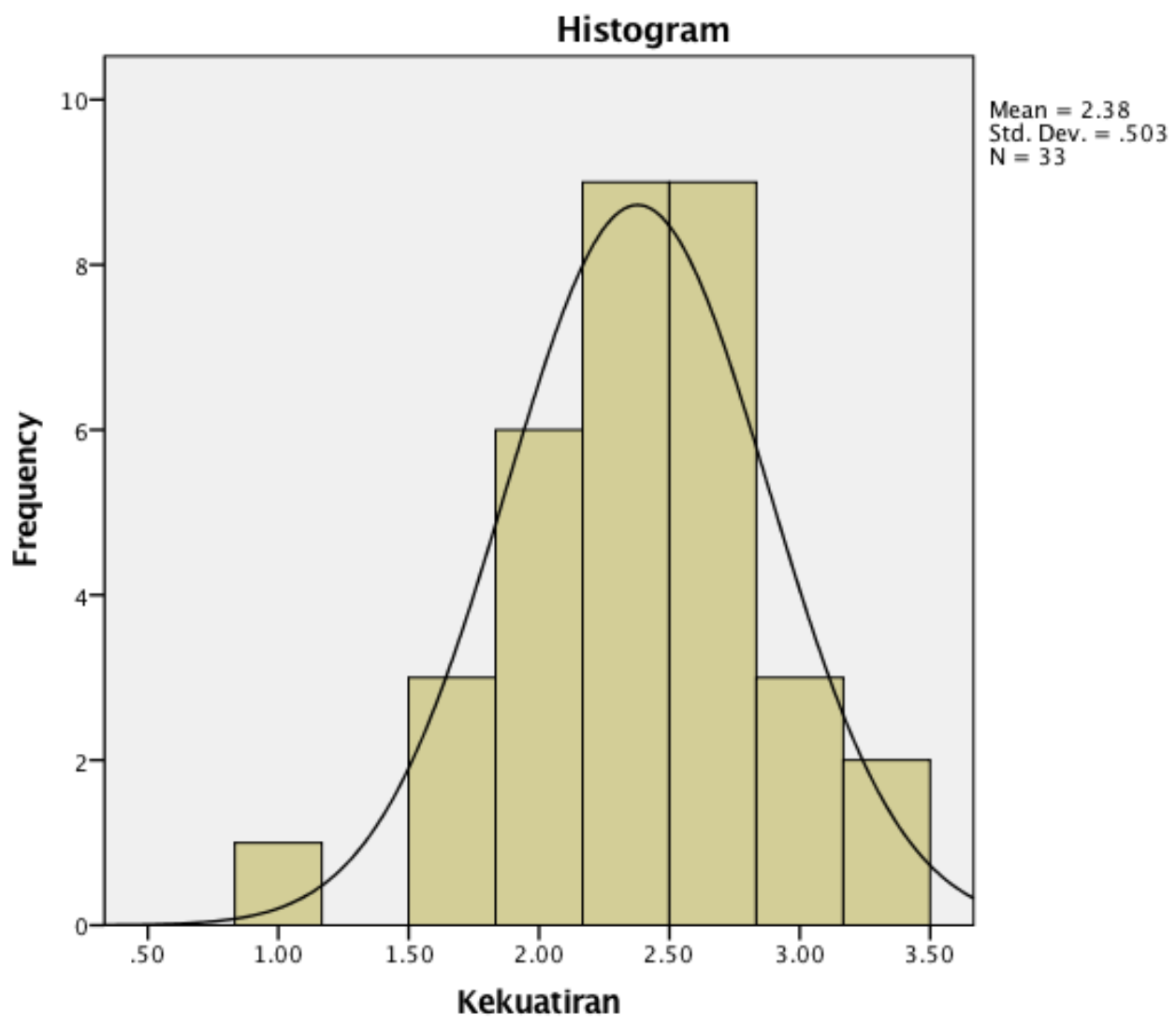

Image of Distribution of Lecturers' Concerns: Based on the histogram above, it appears that although the average lecturer worries are 2.37 , there are quite a number of lecturers who have worries. In this case, as many as 14 lecturers had worries above 2.5 . For this reason, the average value (2.37) needs to be tested with one sample t-tets.

\section{Uji One Sample t-test:}

Tabel of results One Sample t-test

\begin{tabular}{|l|c|c|c|c|c|c|}
\hline & \multicolumn{9}{|c|}{ One-Sample Test } \\
\cline { 2 - 6 } & $\mathbf{t}$ & \multirow{2}{*}{ df } & Sig. (2-tailed) & $\begin{array}{c}\text { Mean } \\
\text { Difference }\end{array}$ & \multicolumn{2}{|c|}{$\mathbf{9 5 \% \text { Confidence Interval of the Difference }}$} \\
\cline { 5 - 7 } & -1.396 & 32 & .172 & -.12222 & -.3006 & Lower \\
\hline Kekuatiran & & &
\end{tabular}

Based on the above table, it appears that the difference between lecturer worries (2.37) with limitation worries (2.5) is -0.12 which means lecturer worries are below the limit. Furthermore, the value of $t$ is -1.39 which is accepted at the error level 0.172 .

\section{Qualitative Research Results}

The concerns of STTBI lecturers on Covid-19 are in varying degrees of severity. However, this research found that there is something that equates one lecturer with another lecturer, namely the mechanism of the anxiety formation itself.

1. In December 2019, the world was shocked by the presence of a new virus, namely covid-19 or corona that occurred in Wuhan, China. At this 
stage, lecturers who already know this information feel normal. This happened to all lecturers. There are several reasons they are not worried about this, namely the distance between China and Indonesia which is quite far, and there have been efforts to localize this incident so that it does not spread outside.

2. In January 2020, Covid began to spread outside of China and new cases occurred in other countries. At this stage, the lecturer has begun to be divided in terms of his worries.

3. In March 2020, the first Covid case occurred in Indonesia. At this stage, the gap between lecturers has begun to increase. Some lecturers who were not yet worried, are now starting to have worries. This is indicated by feelings such as panic, confusion, "parno", and fear. While the lecturers who were still feeling normal, at this stage some began to be vigilant and guarded even though they did not panic.

4. In April 2020, Covid-19 infected students at the Bethel Petamburan Seminary. At this stage, some lecturers who had been panicked, now become dizzy and stressed. While the lecturers who felt normal were no longer there.

Concrete Triangulation Results: The findings obtained in quantitative research are then triangulated with the findings in qualitative research. The process of matching data produces validated data, and data that is not validated. Validated data alone is the final result of this study.

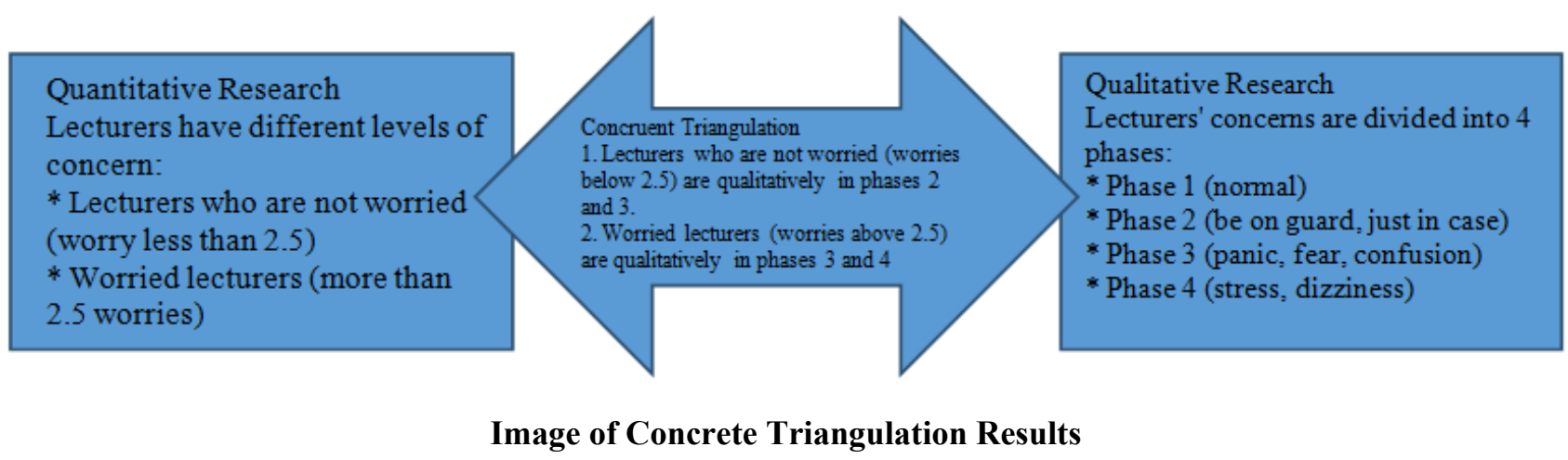

On the results of quantitative research, it is known that there is 1 lecturer who is not worried at all (worries of 1). When this was confirmed in qualitative research, there were no lecturers who were not worried at all. So this data is not confirmed. While lecturers who are in the category of not worrying (scores below 2.5) were found to be in the anxiety phase 2 and 3 . Furthermore, lecturers who had worries (more than 2.5 worries) were found to be in the worry phase 3 and 4 . Nevertheless, it is true that in general lecturers are not worried (as evidenced by the results of quantitative and qualitative research).

\section{Discussion}

Worrying is a universal human experience, because it is certain that everyone must have felt anxiety. It is true that the level of concern for each individual is different. Anxiety is very closely related to anxiety. Anxiety according to McCroskey is a feeling that is owned by every individual. He considers that the emergence of

anxiety involves negative thoughts and feelings so that the consequences lead to unusual behavior and responses ${ }^{7}$. While T E Foose saw an anxiety relationship with phobias. Such conditions actually want to describe the phenomenon, epidemiology, genetics, neurosir circuit, and training of any irregularities, to identify in general and different clusters ${ }^{8}$. Each anxiety instrument is organized cognitively and psychologically to see the reaction it causes.

While in the New Testament, a prominent expression can be seen from the Greek word merimnao, which means "concerned, worried, anxious, and afraid". If the focus on material concern shows weakness or lack of faith. For this reason, understanding the nature of life that depends on God is far more important in worrying about material things ${ }^{10}$.

Another phrase that is used to describe the attitude of worry is the Greek word daag which, if translated 
can be interpreted to be anxious, anxious, afraid, afraid. Referring to various notions of the word "worry" it actually shows clear evidence that humans are limited beings who need help ${ }^{11}$. Thus it can be said that someone who is anxious needs help that is able or able to free himself from being worried.

On the other hand, feelings of worry in humans is one proof of the need for a definite guarantee about the survival of his life. The guarantee covers, among other things physical, mental, spiritual and social health. It is believed that with this guarantee the level of anxiety that brings anxiety to a person can be reduced. Regarding anxiety, it is good to pay attention to what is expressed by McCroskey ${ }^{12}$ that anxiety is an integral part of worry. Anxiety exists in two things namely, state anxiety and trait anxiety. Anxiety in the category of state anxiety is an experience of anxiety that arises in certain circumstances. So, worrying about the category of state anxiety can occur because there are calamities that threaten humanity such as the corona virus case that is endemic globally.

First, individuals experience stress and illness. One important symptom that is easily identified in someone who is anxious in the severe category is stress ${ }^{13}$. Furthermore, according to Rita L. Alkitson et al, stress situations produce emotional reactions ranging from excitement to general emotions of anxiety, fatigue, disappointment, and depression (Hilgard, Atkinson, and Atkinson 1980). It can be ascertained that stress that is not resolved properly will ultimately cause greater pressure on a person and if the condition is getting worse then the next result is the emergence of various diseases.

Second, confusion or apathy. If worries are not managed properly, it will have a wide impact, including causing apathy and depression. In general, apathy is an act of withdrawing from the problem at hand. However, apathy that is not resolved can be fatal because it causes depression. For individuals who are unable to control stress or show powerlessness to solve problems, it will cause apathy ${ }^{14}$.

Third, anxiety. Mental health is a condition where there is no psychopathology, such as depression and anxiety. This is shown in the harmonious relationship between feelings of happiness and satisfaction in life, positive individual functions both towards themselves and the environment ${ }^{15}$.

Fourth, hopelessness or frustration ${ }^{16}$. Feelings of frustration or hopelessness are responses to disappointment towards the failure to achieve targets or goals. It can also be said that frustration is an unpleasant tension, filled with an increasingly higher level of sense and nerve activity. In an effort to achieve something big, hard efforts were made. Frustration as a sense of disappointment with one's failure to achieve a desired hope or ideal, or a sense of disappointment because the expectations and results achieved do not have a match ${ }^{17}$.

Fifth, kill yourself. A person who experiences prolonged depression can result in self-harming actions namely suicide. Depression is an emotional condition characterized by deep sadness, feelings of insignificance and guilt, withdrawal from others, unable to sleep, loss of appetite, sexual desire, and pleasure from what can be done. For people who can't stand the pressure, anxiety can cause someone to commit suicide ${ }^{18}$. The results of this study indicate that the concern that exists in STTBI lecturers is still at a low level. If related to the five indications above, lecturers' concerns only reach the third level, which is anxiety. This is certainly in accordance with the results of quantitative research, namely lecturers do not have significant worries about co-19.

\section{Conclusions}

Based on the results of research that has been done, it can be concluded that it is true that the concerns of STTBI lecturers on Covid-19 still exist in the low category, namely anxiety. However, this concern can develop if information about Covid-19 continues to grow, and the lecturer pays attention to that information. This is consistent with the new findings in this study, namely concerns based on historical information.

\section{Conflict of Interest: None}

\section{Source of Funding: Self}

Ethical Clearance: Obtained from university ethical committee

\section{References}

1. Yang, H. Y., and G. C. Duan. "Analysis on the Epidemic Factors for the Corona Virus Disease." Zhonghua yu fang yi xue za zhi [Chinese journal of preventive medicine]. 2020.

2. Hoque, Ashikul et al. "The Effect of Coronavirus (COVID-19) in the Tourism Industry In." Asian Journal of Multidisciplinary Studies. 2020. 
3. Anxtttynma, Pengaruh Computer. "Dapat Diiihat Dari Kemampuannya Untuk Mengubah Peran Teknologi Komputer Yang Semula Ditempatkan Sebagai Pendukung Pekerjaan Kantor (Back-Offtce Support) Menjadi Aspek Sentral Dari Strategi Organisasi Untuk Perkembangan Konfigurasi Teknologi Komputer Yan. 2000; 4(2).

4. Harimurti, Fadjar, and Dewi Saptantinah Puji Astuti. "Pengaruh Computer Anxiety Terhadap Keahlian Pemakai Komputer Dengan Internal Locus of Control Sebagai Variabel Moderasi." Jurnal Ilmiah Akuntansi dan Bisnis: 2017; 91.

5. Yudha, Ramantha, and Wayan Ramantha. "Pengaruh Computer Anxiety Dan Computer Attitude Pada Keahlian Pengguna Dalam Menggunakan Komputer." E-Jurnal Akuntansi 2014.; 9(3): 644-57.

6. Creswell, John W. "A Concise Introduction to Mixed Method Research." Doc1.Bibliothek.Li. 2015

7. Mccroskey, James C. "Oral Communication Apprehension: A Reconceptualization." Annals of the International Communication Association. 1982

8. Foose, T. E. "Anxiety." In Encyclopedia of the Neurological Sciences,. 2014

9. Brown, Colin. "Dictionary of New Testament Theology - Vol. 1." Journal of the Evangelical Theological Society 2002; 45(1): 152.
10. Walvoord, John F, and Roy B Zuck. 2 The Bible Knowledge Commentary Old Testament. 1983.

11. Spencer, F Scott. "To Fear and Not to Fear the Creator God: A Theological and Therapeutic Interpretation OfLuke 12:4-34." Journal of Theological Interpretation 2014.; 8(2): 229-49.

12. McCROSKEY, James C. "Oral Communication Apprehension: A Summary of Recent Theory and Research." Human Communication Research. 1977.

13. Brown, Beth E. "Dealing with Fear, Stress, and Anxiety in the Learning Environment." 1982; V(1): $48-52$.

14. Hilgard, Atkinson, and Atkinson. "Review of Introduction to Psychology, 7th Ed." Contemporary Psychology: A Journal of Reviews. 1980

15. Westerhof, Gerben J., and Corey L.M. Keyes. "Mental Illness and Mental Health: The Two Continua Model across the Lifespan." Journal of Adult Development. 2010

16. Miller, N. E. "I. The Frustration-Aggression Hypothesis.” Psychological Review. 1941.

17. KBBI. "Kamus Besar Bahasa Indonesia (KBBI)." Kementerian Pendidikan dan Budaya. 2016

18. Donohue, Meghan Rose, and Joan Luby. "Depression." In The Curated Reference Collection in Neuroscience and Biobehavioral Psychology. 2016. 